\title{
Many paths to walk. The political and economic integration of nomadic communities in Roman North Africa (I-III cent. A.D.)'
}

\author{
Wouter Vanacker \\ Department of History, Ghent University
}

\begin{abstract}
The colonial image of endemic political and economic antagonism between nomadic and sedentary groups in the context of Roman North Africa should be discarded. Likewise, the rigid adherence to symbiosis and cooperation in more recent studies is based on a rather one-sided reading of anthropological literature. For the analysis of literary, epigraphic and archaeological sources, supported by insights derived from anthropology, shows that political and economic integration trajectories of nomads were much more complex, diverse, and dynamic.
\end{abstract}

Key words: Nomads, integration and insurgence, North Africa, Roman imperialism, coexistence patterns, transSaharan trade, clio-anthropology

\section{Introduction}

Research of Roman imperialism in North Africa (Africa Proconsularis, Mauretania Tingitana and Caesariensis) during the first four centuries A.D. has been deeply marked by colonialist and nationalist ideologies. The 'unwillingness' of indigenous groups to accept the modern colonial construct and (what was seen as) civilization was extrapolated to historical accounts of ancient interrelations between nomadic and sedentary groups. The result was a nearly one-sided historical image of endless conflict and hostility. The strong involvement of the French army in the reconnaissance of archaeological and epigraphic indicators of Roman presence illustrates the state of affairs in the colonies as much as it reveals the nature of a conscious imperialist ideology to imitate and emulate Roman rule. French and Italian scholars in fact perceived their contemporary empires as the inheritors of a long lost civilization, and this ideology was used to justify its colonial aims and claims (cf. Dondin-Payre, 20II; Munzi, 20I2). At this time the ideology of the "permanence berbère" came to see the light: it was held that the failure of Roman imperialism in North Africa originated from its inability to obliterate the remnants of a 
tenacious but passive and primitive Berber culture. It was collated on another scholarly paradigm, a spatial division between plains of accommodation and mountains of resistance. Modern colonial powers had to do better:

"Parviendrons-nous jamais à transformer la société indigène assez complètement pour la pouvoir assimiler, et réussirons-nous là où Rome a échoué?" (Cagnat, I9I2:775-776)

The post-colonial reaction among North African scholars presented a similar image of the survival of pre-Roman indigenous features of socio-political structure and culture. The "permanence berbère" continued to emerge in these studies, but it was now considered a positive thing. Early nationalist studies continued the binary oppositions based on ethnicity, celebrating the survival of a culture against foreign occupation, the persistence of "l'âme africaine" (for instance Laroui, I970; Bénabou, 1976, quote:353). The modern colonial dichotomy was not overcome, and maximalist representations of antagonism flourished. Scholars argued that:

"la Pax romana n'a été qu'un euphémisme masquant une réalité africaine: l'insurrection quasi continue des Berberès contre l'occupation étrangère." (Kaddache, I972, III)

After independence, the appropriation of the past continued and received an unexpected twist. In a reaction against Arab oppression of Berber identity, the history of Numidia before the Arab invasions has become the object of idealization among modern Kabylian Berber communities (Fenwick, 2007, 8I). In different countries (Algeria, Tunisia) an exclusive claim is made on the heritage of the ancient Numidian kingdom. Children are called "Numidia" and "Masinissa", one "Takfarinas" sings Kabylian ballads. A reality of resistance is embedded in the image of an "eternal Iugurtha". There is a paradoxical tendency to depend on classical sources to describe and legitimize an independent ethnic identity (Silverstein, I996, I4; Ghambou, 2010).

In 1978 Whittaker deduced from anthropological studies that nomads and sedentary groups could coexist in a positive way after all. Shaw's similar observations were fundamentally based upon analogous anthropological observations (Whittaker, I978; Shaw, I980). By doing so, the doctrine of continuity or "permanence" was taken to a higher level, now leaving at least some place for the nomadic livelihood. Gutsfeld's study on military interactions went in the same direction as it added nuance to the bloody image of settled-nomadic interrelations shaped especially by French and Italian scholarship (Gutsfeld, I989). These efforts created minimalist representations of insurgence and narratives of symbiosis. But in the meantime, the image of resistance and antagonism continued to flourish and the application of anthropological models damaging established reconstructions of conflict received notable criticism (Bénabou, I986, I4I; Leveau, I988). 
Influenced by the appreciation in most recent studies to highlight discrepancy and differentiation in the way various peoples, groups and individuals experienced and processed Roman influences, the present doctoral study intends to advance beyond the rigid and tendentious perspectives discussed above. Scholars such as Woolf (I998), Hingley (2005) and Mattingly (20II) have encouraged their colleagues to accept fluidity and diversity with respect to the social, cultural, economic and political processes in subjugated areas (and beyond). These studies confirm the need to readdress the following research question: how did nomadic communities in North Africa integrate in the political and economic structures within the Roman Empire? This research question elicits a plethora of lower order questions, which we addressed and elaborated on throughout the thesis. What were the causes and nature of tribal insurgence? What motivated the execution of Ptolemaeus by A.D. 39, the client king of Mauretania, and what were the origins of the Moorish leader Lusius Quietus, who attained the position of Roman consul possibly in A.D. II7? Could the economic adoption of the camel have influenced frontier instability in the later Roman Empire? And what about the impact of environmental changes? What was the nature and scale of the trans-Saharan trade in classical times, and the involvement of nomadic communities? What could have motivated the appointment of state agents among tribal communities? But the study also attempted to contribute to more fundamental discussions. What does the evidence say about the role of pre-existing societal structures in the design of indigenous integration trajectories? What can we learn about the permeability of the frontier or the nature of Roman imperialism in this period? The chronological margins of the project comprise the first three centuries A.D., though we sometimes surpass these chronological limits in order to grasp the nature and longterm effects of political and economic developments.

The main part of the study attempts to provide a valid interpretation of the political and economic integration of nomadic communities in Roman Africa. The first chapter allows for an insight in the nature of the nomadisms practiced and the ecological context in which they appeared and evolved. With respect to the second chapter devoted to the political integration patterns it should be argued that we have deliberately opted for a thematic approach. For, it is shown, a chronological framework may give rise to misleading interpretations of insurgency in the region. Features of opposition and antagonism have been assembled in the first subchapter, traces of symbiosis are presented in the second. The next major theme of the study deals with the economic integration. The first discussion considers the ways nomadic economies within the imperial context changed in response to new opportunities and challenges. In the next subchapter entitled "The Saharan Boom" the impact of empire on desert communities is assessed. Roman presence in the desert proper is looked for, and considerable attention is paid to the rise of trans-Saharan trade in this period. A fourth chapter presents two major case studies of tribal (political) integration. They add strength to our conception of variability and differentiation in the nature of Roman imperialism and integration. There is an elaboration on a number of crucial determinants, shifts and drifts of these processes in the fifth chapter. 


\section{Methodology}

Ancient literary accounts on nomads in North Africa, if present, obviously lack the modern approach and standards of modern anthropology and ethnography. They regularly fail to provide much of the basic information needed for a thorough analysis and characterization of internal social, economic and political structures. Generally, ancient authors treated nomadic societies with despise: nomadic societies were seen as being cultureless, disorderly and savage, a product of the wild environment and their own indolence. The literary sources maintain a grand divide between pastoralism and agriculture. By doing so, they emphasize an image of opposition between nomadic and settled inhabitants, between the desert and the sown. "Ethnographical" descriptions of North African nomads in Greek and Latin literature are substantially based on stereotypical conventions. Other shortcomings can be revealed as well, which often render the detailed identification of tribal groupings and their socio-political structures nearly impossible. Fortunately, there is also epigraphic evidence at the disposal of the ancient historian. A major advantage of these sources is the indigenous agency in their creation. Inscriptions can elucidate the long term cultural, political and social developments indigenous groups may or may not have undergone. Nomadic peoples are often poorly attested in the archaeological record: their material culture often lacks the quantitative and qualitative dimensions that actually induced their preservation and discovery. But archaeologists and their funders were and are usually much more thrilled to discover and study the splendour of the ancient city and its rural integration. Nomads were and are supposed to fill the empty holes on the map. The result is that conventions of antagonism between the desert and the sown are maintained. But an archaeology of polar oppositions may mask a historical reality of in-betweens.

One way to overcome the uneasy source situation was to use and critically compare the broad spectrum of different source types available. Another is to implement an interdisciplinary approach. The present study has drawn a lot of insights from Khazanov, for many beneficial developments in modern nomadology have converged in his monumental work "Nomads and the Outside World" (Khazanov, I994). The use of Khazanov's model, supplemented with additional studies in fact enabled us to by-pass some of the shortcomings in the sources by providing a framework that can help contextualize and interpret the erratic pieces of information supplied by the sources. Importantly, the doctoral thesis combines different approaches or levels of interpretation applied in anthropological research to study nomadic groups. A survey of interfaces (e.g. periodic markets, elite mediators,...) and socio-ecological developments (e.g. increasing social stratification as a consequence of external political influences, climate change and its effects) are realized within a wide regional circumscription (Salzman, I978; Dyson-Hudson \& Dyson-Hudson, I980, 37f). By doing so, a contribution is made to what has been termed clio-anthropology: the fruitful merger of history and anthropology to comprehend and compare societal processes and structures in the past and present. For the results may prove themselves useful not merely for (ancient) historians, but also for anthropologists who value the diachronic approach. 


\section{Principal results}

Epigraphic and archaeological sources are crucially important in revealing that the nomadic mode of production or tribal political organization was not necessarily an impediment to integration in the Roman imperial construct. We have shown that anthropological studies can make an important contribution to the analysis of the sources. Symbiosis was only one side of the coin, and could take many forms. Anthropologists have produced a wide variety of insights in and models of coexistence between sedentary and nomadic peoples, emphasizing the diversifying effects of cultural, social, economic, political and environmental factors shaping these coexistence patterns. With respect to many North African tribes of antiquity, we lack much detail about these factors. Therefore, we can often pose only very hypothetical answers to some questions the anthropological studies elicit. This is unfortunate. However, we should not discard these answers altogether as they may succeed in elucidating the very hypothetical if not doubtful nature of prior reconstructions and existing conceptions.

Political and economic integration is best understood in terms of differentiation and discrepancy. Despite the scarcity and biased nature of the sources, models of differentiation developed convincingly in recent archaeologist studies on material culture can be applied successfully to the field of political and economic integration of nomadic tribes in and along Roman Africa. Differentiation resulted from the fact that the nature and scale of integration were based on several internal and external factors. It was the specific constellation of various variables that gave rise to discrepant integration trajectories: Roman political and economic ambitions in the region, Roman military capacities, ecological conditions, intratribal and intertribal socio-political relations, opportunities of adaptation or reconversion for the nomadic economy, and pre-Roman external influences of urbanization, commercial integration and political centralization. Since the collective nature of these features differed from tribe to tribe, from context to context, dogmatic interpretations resulting from the rigid adherence to antagonism or symbiosis perspectives will always fall short in explaining the complex heterogeneity of integration. Another implication is that, contrary to what is often presumed, explanations drawn from better known cases such as the Tacfarinas uprising are far less likely to provide a key to understanding other poorly attested conflicts. Moreover, the determinants of integration are liable to change, and so are tribal integration trajectories.

Political integration involved mediated interaction between tribal elites and Roman authorities, as well as Roman adaptation of its imperial tools. Importantly, association and successful negotiation with Roman authority could have had a beneficial effect on the social and political status of individuals within the tribe. However, various setbacks challenged the importance of Roman citizenship as a tool to accumulate and preserve status and power within a tribal segment. The evidence on the principes and praefecti gentis (leaders recognized by the Roman administration and state agents, respectively) illustrates the importance of pre-existing structures among the subjugated peoples in the process of political integration. Tribal political structures necessitated Roman adaptation of its administrative tools in order to stabilize and extend its imperial rule. From a 
political point of view, it was by integrating pre-existing political structures that Rome often succeeded in integrating the tribes into her imperial orbit. The specificity of the format of imperial rule adds another part of the multi-checked appearance of Roman imperialism not merely in Roman Africa but also in the empire generally.

Finally, new insights have been elaborated in the development of the trans-Saharan trade. Contrary to what has currently been believed, it is shown that the demise of urban centres among the Garamantes in Central Libya did not inevitably entail a sharp decline of trans-Saharan trade from the third century A.D. onwards.

\section{Conclusion}

A large variety of integration patterns indicate that nomads were not naturally hostile to integration, and that Roman policy did not aim at the inclusion of agriculturalists and town-dwellers only while containing or expulsing the nomadic population. These integration trajectories were not the outcome of some happenstance or of a 'natural' aptitude to coexistence. It resulted from a variety of dynamic determinants shaping these integration trajectories. The conquered tribes integrated in different ways in the imperial construct. But Rome also adapted its imperial toolset to the societal structures it conquered. The precise nature of integration depended on a variety of factors. Successful integration of subjugated tribes should not be understood only in terms of observing territorial advance of forts or counting towns bequeathed with advanced privileges and rights, municipia and coloniae. Colonial and post-colonial scholars alike have created an incomplete perspective on the political integration of indigenous tribes in North Africa because it is based exactly on the erroneous choice and interpretation of the variables to measure this process. Anthropology has shown that nomadic societies have their own dynamics, pastoralist economies have their own determinants. We should recognize that much of the knowledge we lack is not merely a consequence of the source situation, but also the fruit of presumption and neglect: one will not find anything if one does not bother to look. The influence of archaeologists and their focus on urban culture may have provided an over-emphasis of the urban face and prerequisite of Roman imperialism. It is conventional to state that Rome's empire was built on cities. This study has shown that it could also have been built without them.

\section{References}

Bénabou, M. (I976). La résistance africaine à la romanisation. Textes à l'appui. Histoire classique. Paris: F. Maspero. (I986). L'Afrique. In: Crawford, M.H. (ed.), L'impero romano e le strutture economiche e sociali delle province. Como: New Press, pp. I27-I4I.

Cagnat, R. (I9I2). L'Armée romaine d'Afrique et l'occupation militaire de l'Afrique sous les empéreurs. Paris: Leroux.

Dondin-Payre, M. (20II). Empire antique, empire contemporain: l'Afrique du nord. In: Benoist, St. et al. (eds.) Figures d'empire, fragments de mémoire: pouvoirs (pratiques et discours, images et représentations), et identités (sociales et religieuses) dans le monde romain impérial (Ier s. av J.-C. - Ve s. ap. J.-C.). Villeneuve d'Ascq: Presses Universitaires Septentrion, pp. 49-70.

Dyson-Hudson, R. \& Dyson-Hudson, N. (I980). Nomadic Pastoralism. Annual Review of Anthropology 9 , pp. I5-6I. 
Fenwick, C. (2007). Archaeology and the Search for Authenticity: Colonialist, Nationalist and Berberist Visions of an Algerian Past. In: Fenwick, C. et al. (eds.), TRAC 2007: Proceedings of the Seventeenth Annual Theoretical Roman Archaeology Conference (University of London), at London. Oxford: Oxford Books, pp. 75-88.

Ghambou, M. (2010). The "Numidian" Origins of North Africa. In: Hoffman, K.E. \& Miller, S.G. (eds.), Berbers and Others: Beyond Tribe and Nation in the Maghrib. Bloomington: Indiana University Press, pp. 153I70.

Gutsfeld, A. (1989). Römische Herrschaft und einheimischer Widerstand in Nordafrika. Stuttgart: Franz Steiner Verlag.

Hingley, R. (2005). Globalizing Roman Culture: Unity, Diversity and Empire. London: Routledge.

Kaddache, M. (1972). L'Algérie dans l'antiquité. Madrid: Altamira-Rotopress.

Khazanov, A.M. (1994). Nomads and the Outside World. Madison: University of Wisconsin Press.

Laroui, A. (I970). L'histoire du Maghreb: un essai de synthèse. Paris: F. Maspero.

Leveau, Ph. (I988). Le pastoralisme dans l'Afrique antique. In: Whittaker, R.C. (ed.), Pastoral Economies in Classcial Antiquity. Cambridge: The Cambridge Philological Society, pp. 177-195.

Mattingly, D.J. (20II). Imperialism, Power, and Identity: Experiencing the Roman Empire. Princeton, N.J.: Princeton University Press.

Munzi, M. (2012). Italian Archaeologists in Roman Tripolitania. Libyan studies 43: pp. 8I-IIO.

Salzman, Ph.C. (1978). The Study of'Complex Society' in the Middle East: a Review Essay. International Journal of Middle East Studies 9 (4): pp. 539-557.

Shaw, B.D. (I980). Fear and Loathing: the Nomad Menace and Roman Africa. In: Wells, C.M. (ed.), Roman Africa (The Vanier Lectures, Ottawa). Ottawa: The University of Ottawa Press, pp. 29-50.

Silverstein, P. (1996). Realizing Myth: Berbers in France and Algeria. Middle East Report (200): pp. II-I5.

Whittaker, C.R. (1978). Land and Labour in North Africa. Klio 6o (2), pp. 331-362.

Woolf, G. (1998). Becoming Roman. The origins of provincial civilization in Gaul. Cambridge: Cambridge University Press. 